\title{
Microbiological Assay for Purine Analogues with Lactobacillus casei
}

\author{
By M. J. HARBER AND J. L. MADDOCKS \\ K.R.U.F. Institute of Renal Disease, Welsh National School of Medicine, \\ The Royal Infirmary, Cardiff
}

(Received 20 June 1973)

INTRODUCTION

Hitchings et al. (1950) utilized the growth requirements of Lactobacillus casei in their search for antimetabolites that block nucleic acid synthesis. 6-Mercaptopurine (6-MP) markedly inhibited the growth rate of $L$. casei and possessed powerful antitumour activity (Skipper, 1954; Biesele, 1954) and immunosuppressive properties (Schwartz, Stack \& Dameshek, 1958; Calne, 1960). Azathioprine is an imidazole derivative of 6-MP which is rapidly converted to 6-MP in vivo by a non-enzymatic hydrolysis in the presence of sulphydryl groups (Elion, Callahan, Bieber, Hitchings \& Rundles, I96I). Both 6-MP and azathioprine are used extensively in the treatment of patients with malignant disease, organ transplants and auto-immune disorders. Drug dosage is usually adjusted according to the peripheral white cell count because no method of assay is available for estimating therapeutic blood levels. In this communication we present a microbiological method of estimating nanogram quantities of azathioprine and 6-MP in aqueous solution.

\section{METHODS}

Basal medium. A modification of the folic acid assay medium described by Waters \& Mollin (I96I) was used. Excess folic acid $(20 \mathrm{ng} / \mathrm{ml})$ was included in the medium but purines and pyrimidines were omitted. Buffering capacity was increased by addition of $0.2 \mathrm{M}$ Sörensen's phosphate buffer, pH 6.6 (500 ml/1), and acid-hydrolysed vitamin-free casein (Difco) was used instead of enzyme-hydrolysed casein. A slight precipitate appeared on autoclaving but cleared on cooling.

Lactobacillus casei ATCC 7469 was maintained on agar slopes prepared by adding a mixture of $5 \mathrm{mg} / \mathrm{l}$ of each of adenine sulphate, guanine hydrochloride and uracil to the singlestrength medium solidified with $2 \%$ (w/v) Bacto-Agar (Difco). A stock liquid culture in Io $\mathrm{ml}$ of single-strength medium with added purines and pyrimidines was sub-cultured daily. The inoculum was prepared by washing the bacteria from a $24 \mathrm{~h}$ broth culture twice with sterile $\mathrm{NaCl}(0.9 \%, \mathrm{w} / \mathrm{v})$ and finally resuspending in $\mathrm{NaCl}$ to $E_{560}$ of 0.05 units.

Standard solutions. Imuran azathioprine for injection (Burroughs Wellcome \& Co., Dartford, Kent) in vials containing the equivalent of $50 \mathrm{mg}$ free drug as the sodium salt was used. Mercaptopurine B.P. (6-MP; 100 mesh B.S.S.) was obtained from Burroughs Wellcome \& Co. Due to the limited solubility of both drugs in water, $50 \mathrm{mg}$ of each was dissolved in $20 \mathrm{ml}$ of $0 . \mathrm{I} \mathrm{M}-\mathrm{NaOH}$ and then diluted immediately to $500 \mathrm{ml}$ with distilled de-ionized water to give Io0 $\mu \mathrm{g} \mathrm{drug} / \mathrm{ml}$. Stock aqueous solutions of azathioprine and 6-MP in the range 20 to $2000 \mathrm{ng} / \mathrm{ml}$ were prepared. These solutions were stored at $4{ }^{\circ} \mathrm{C}$ and used within $24 \mathrm{~h}$ of preparation. 

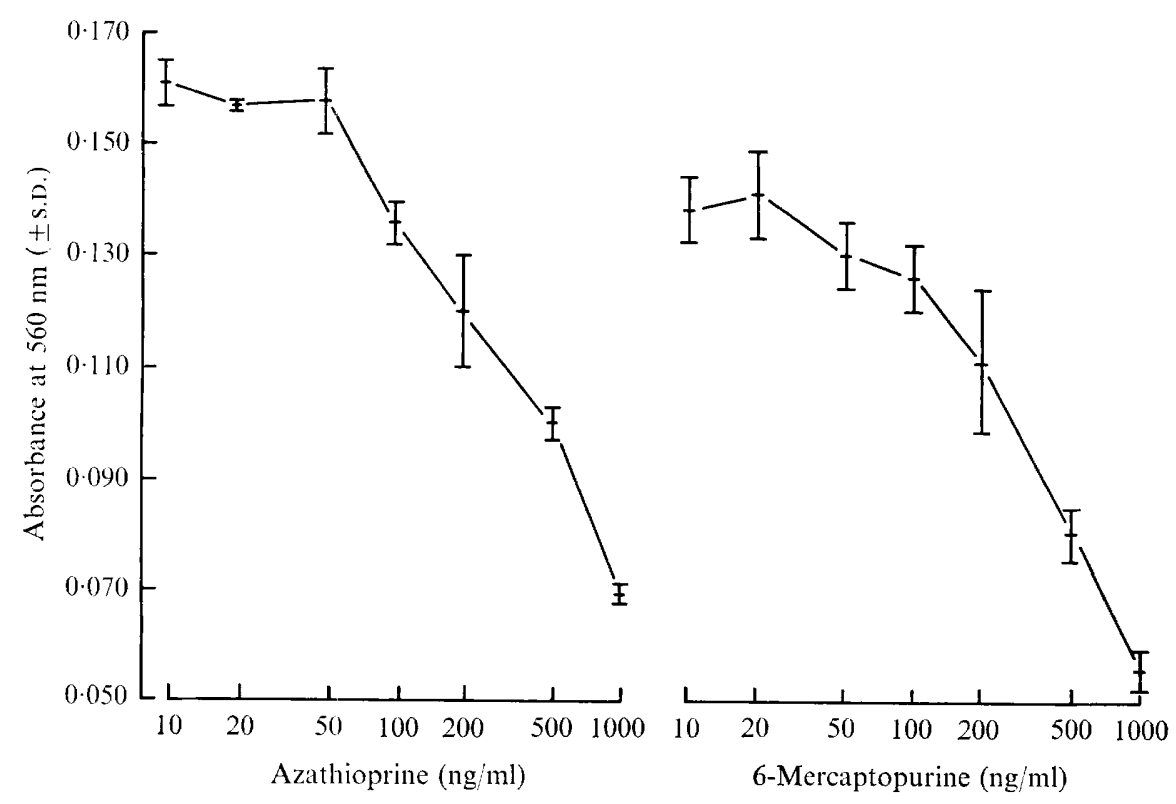

Fig. I. Growth inhibition of Lactobacillus casei by azathioprine and 6-mercaptopurine.

Assay procedure. Two $\mathrm{ml}$ of double-strength basal medium were added to $2 \mathrm{ml}$ of each stock solution (in triplicate), plus four water blanks, to give standards containing to to $1000 \mathrm{ng} / \mathrm{ml}$. The assay tubes were closed with aluminium caps and autoclaved at $10 \mathrm{lb} / \mathrm{in}^{2}$ for $10 \mathrm{~min}$. When cool each tube except one blank was inoculated with 2 drops of Lactobacillus casei from a Pasteur pipette ( $50 \mathrm{drops} / \mathrm{ml}$ ) and incubated at $37^{\circ} \mathrm{C}$ for $\mathrm{I} 8 \mathrm{~h}$. Growth was dispersed on a vortex mixer, and turbidity at $560 \mathrm{~nm}$ was measured in a Unicam S.P. 600 spectrophotometer.

\section{RESULTS}

Growth inhibition commenced at approximately $50 \mathrm{ng}$ of azathioprine or 6-MP/ml. The regression line $y=a+b x$ was fitted to the data for each individual assay in the range 50 to $1000 \mathrm{ng} / \mathrm{ml}$. The value $x$ represents $\log _{10}$ concentration minus the mean $\log _{10}$ concentration. Good correlation between growth level and drug concentration was consistently obtained. The mean correlation coefficient $(r)$ for seven azathioprine assays was -0.965 and for eleven 6-MP assays was -0.985 . Typical growth inhibition curves for azathioprine and 6-MP are shown in Fig. I. The correlation coefficients for the data presented are -0.992 for azathioprine and -0.974 for 6-MP. The residual standard deviations were 0.006 and 0.009 respectively.

\section{DISCUSSION}

It is surprising that no microbiological assay technique for azathioprine or 6-MP has been described previously because the Lactobacillus casei model played a major role in the development of both drugs. Following the discovery of 6-MP as a powerful antimetabolite many microbiological studies were undertaken with large concentrations of drug (up to $240 \mu \mathrm{g} / \mathrm{ml}$ ), but they were designed mainly to further understanding of the mechanism of action of 6-MP (Balis et al. I957) and were qualitative rather than quantitative.

The microbiological assay reported here is considerably more sensitive than both u.v. 
spectroscopy and the colorimetric estimation for 6-MP described by Loo \& Michael (1958), which allow detection in the microgram range only. The sensitivity is equalled by a fluorimetric assay for purine-6-sulphonate, an oxidation product of 6-MP (Finkel, 1967), but the microbiological technique has the advantage of utilizing basic laboratory equipment only. Although greater accuracy might be desirable the degree of error involved is probably no greater than in the majority of microbiological assay methods.

Studies with radioisotopes by Burroughs Wellcome \& Co. (1969) indicated that the peak level of 6-MP in human plasma following oral administration of therapeutic doses of azathioprine (I to $3 \mathrm{mg} / \mathrm{kg}$ ) is unlikely to exceed I $\mu \mathrm{g} / \mathrm{ml}$. This is the limit of sensitivity of the fluorimetric method of Finkel (1967) when used to estimate 6-MP in plasma. The microbiological method described should be sufficiently sensitive for the estimation of pharmacological levels of 6-MP in biological fluids if coupled with a suitable extraction procedure.

We are grateful to Dr A. W. Asscher for his helpful advice and discussion.

\section{REFERENCES}

Balis, M. E., Levin, D. H., Brown, G. B., Elion, G. B., Nathan, H. C. \& Hitchings, G. H. (I957). The effects of 6-mercaptopurine on Lactobacillus casei. Archives of Biochemistry and Biophysics $7 \mathbf{r}$, $358-366$.

BIESELE, J. J. (1954). Effects of 6-mercaptopurine on experimental tumours in tissue culture. Annals of the New York Academy of Sciences 6o, 228-234.

Burroughs Wellcome \& Co. (U.S.A.) INC. (I 969). Azathioprine (Imuran) $50 \mathrm{mg}$ scored tablets: an adjunct for the prevention of rejection in renal homotransplantation. Clinical Pharmacology and Therapeutics Io, I36-14I.

CALne, R. Y. (1960). The rejection of renal homografts. Inhibition in dogs by 6-mercaptopurine. Lancet $\mathbf{r}$, $417-418$.

Elion, G. B., Callahan, S., Bieber, S., Hitchings, G. H. \& Rundles, R. W. (I96I). A summary of investigations with 6-[(I-methyl-4-nitro-5-imidazolyl)thio] purine (B.W. 57-322.) Cancer Chemotherapy Reports 14, 93-98.

Finkel, J. M. (I967). A fluorometric method for the estimation of 6-mercaptopurine in serum. Analytical Biochemistry 21, 362-371.

Hitchings, G. H., Elion, G. B., Falco, E. A., Russell, P. B., Sherwood, M. B. \& Vanderwerf, H. (I950). Antagonists of nucleic acid derivatives. I. The Lactobacillus casei model. Journal of Biological Chemistry $\mathbf{1 8}, \mathrm{I}-9$.

Loo, T. L. \& MiCHAEL, M. E. (1958). A colorimetric method for the determination of certain purine antagonists. Journal of Biological Chemistry 232, 99-106.

Schwartz, R., Stack, J. \& DamesheK, W. (1958). Effect of 6-mercaptopurine on antibody production. Proceedings of the Society for Experimental Biology and Medicine 99, 164-167.

SkIPPER, H. E. (I954). Effects of 6-mercaptopurine on experimental tumours. Annals of the New York Academy of Sciences 6o, 267-272.

Waters, A. H. \& Mollin, D. L. (I96I). Studies on the folic acid activity of human serum. Journal of Clinical Pathology r4, 335-344. 